\title{
Campus Football Must be Based on the Curriculum Reform of Physical Education and Target Management*
}

\author{
Qilian CHENG, Meifang ZHOU per 1st and 2nd \\ P.E Department \\ Jiangxi Normal University \\ Nanchang, China \\ chengqilian@sina.com
}

\author{
Xueting JIANG, Danyang LI and Yumo ZHOU per \\ 3rd, 4th and 5th \\ P.E Department \\ Jiangxi Normal University \\ Nanchang, China \\ 562780393@qq.com
}

\begin{abstract}
Football, the competitive game with ball with running, has a long history in China. It's necessary to implement the policy "stating from children" so as to make football return home and achieve the dream of powerful country of football. The rapid prosperity of China has changed people's life ways, in which digitized life way has bred children' laziness and led to slump of students' physical health. "Campus football" prevailed recently must meet the demand of scientific outlook on development and curriculum reform of physical education in primary and secondary schools to improve students' 3D health and their competitive capacities in playing football with running to achieve the dream of powerful country of football
\end{abstract}

Keywords-campus football, starting from children, playing football with running, quality of endurance, three-dimensional health, stereo-metric module education

\section{INTRODUCTION}

There are 200 million students in our primary and secondary schools, which provides an immense space and special training base for implementing campus football. As for those educational staff engaged in fundamental subjects education of athletics, they have to set foot in primary and secondary schools to reform PE curriculum at first and supervise and inspect on campus football as well as implement target management in human and material resource in real term in order to finish the general project of "Improving running capacity to ensure Chinese football ascends the forefront in Asia and reaches the Word Cup". Recently, I reread the essay "Analysis and solutions towards the situation of campus football implementation in primary and secondary schools in Nanchang" written by Zhang Rui, a graduate in Jiangxi Normal University. The author has made a lot research with 46 schools involved. He has studied in wide range, including the leaders from educational and sports departments, relevant experts, coaches together with football team members accounting to 1345 . His comprehensive and deep research reflects indeed that football in Nanchang City and surroundings has a poor foundation and campus football suffers a late startup. Influenced by examination-oriented education, students" "physical examination capacities" decreased significantly, especially their cardiovascular system and respiratory system function; it's common that students are not willing to participate in excises. The physical testing standards for boys 1000 meters (girl 800 meters) run continues to lower, but the majority of students still can not reach the standard, even several sudden death cases in endurance running test happened in our country, having arose high attention of national education and sports departments. Therefore, a profound educational revolution about campus football and endurance running curriculum is now emerging in primary and secondary schools. $\mathbf{I}$

Having this in mind, this project, based on reality, objectively analyzes the current situation of campus education and PE curriculum as well as students' excises and physical health. Investigations, reading of literature and analysis of statistics have been used to explore the reform path of PE curriculum in primary and middle schools to effectively improve physical education quality, vigorously promote and advance the development of the campus football and playing football and running level for achieving the remote target of Chinese dream of powerful country of football

\section{ANALYSIS AND STUDY}

\section{A. Transformation of Educational Guiding Principle Should Start from the Quality of PE Curriculum}

Football should be put on the education list starting from improving quality of physical education curriculum in order to carry out campus football successfully. Can campus football be prosperous and powerful country of football be achieved step by step only through strengthening educational management and transforming the guiding theory that runs schools.

First priority should be given to transformation of education guiding principles to get rid of examination-oriented education thoroughly in order to improve quality of PE classes in primary and secondary schools as well as average up students' health. Since the recovery of college entrance examination in 1977 and reform and opening up in 1978, especially after the transformation from distribution system of 
college graduates to employment and business setup by themselves, people begin to realize that knowledge is power and it can change fate. As a result, the aspiration for knowledge has become the highlight of social cognition. Those who can not adapt themselves in militarization study and life will be kicked out, which seems not to meet humanitarian education regulars. However, they pride themselves on proportion of students entering colleges and 100 even 150 students admitted by Qinghua University or Peking University. Schools are not military camps. They can not replace teenager with different characteristics with same steps. Active and decentralized thinking patterns and characteristic and initiative mental model have been taken place by cramming leaning methods. According to the survey on the students admitted by Qinghua University and Peking University, it's incredible that those who favor the militarization education in Hengshui High school should account to $95 \%$. It deserves further studying. As a result, we have to, in a new vision, analyze and study the substantial problems not only from the historical vision but also social reality. It's because that Hengshui High school has sent them into Qinghua University and Peking University which change will those students' fates from remote villages and deep mountains that makes them grateful. They think that hardworking deserves payback. However, everything has two sides. Even though the author have not investigated the physical heath of students from villages who admitted by Qinghua University and Peking University, they were born in mountains and lived unattended life since very young. They walked to school which was a kind of exercise helping them to be hard working and diligent. They took entrance to Hengshui High school as the first step to achieve their goals, and admittance to Qinghua University and Peking University as the second one, and they came to the third one to start up their own business. ${ }^{\text {[21 }}$

However, students born in cities especially post 90s grew up in happiness and sweetness. They lived in comfortable skyscrapers with modern elevator and they went to school by private cars, electric motor or bus. Parents are always hopeful for their only child taking studying and going to college as first target. Getting high scores became a mental burden of modern youth. Owing to the great pressure of study and lack of regular physical exercise, adolescent students' physical health decline universally. Although they are admitted by university, their endurance has declined for 25 consecutive years and physical strength has been in the doldrums. The root lies in the low quality of physical education in primary and secondary schools. Parents in order not to let the children lose at the starting line force their children to learn overtime and reduce playing time, so that many children lost their happy childhood. Lack of systematic endurance exercise has caused sudden death in the half marathon the game, 1000 meter run endurance test, even on the basketball course. It worthy our thinking that the young life lost vitality. The source should focus on the quality of sports education in school with foundation of building bodies.
Everything has inherent law. It's been proved by scientific experiment that long-distance running does good to exercise cardio-pulmonary function. People adhere to long-distance running can improve their lung vital capacity consistently. Experts in heart disease believe that people rarely run with arrhythmia cordis or have hidden cardio cerebral vascular disease or mild chest tightness, headache, dizziness symptoms would be likely to suffer sudden death. Sudden death in medical definition refers to the unexpected death caused by underlying diseases or dysfunction of seemly healthy people in daily life, which is precisely influenced by students' pressure of crossing-footlog college entrance examination, parents' indulgence and expectations as well as inactivity formed gradually and laziness in outside activities. According to the 270000 sampling survey by Ministry of Health in 2010, hypertensive patients increased $31 \%$ than last 10 years, and that in Nanchang has reached $18 \%$ which highly concentrated in high school and college students aged 16-20, forming a group of young hypertension patients. There were sudden death happened several years ago while running in some regional schools but they chose passiveness instead of facing it. However, the PE teachers in Tsinghua University and Dalian University of technology suppressed interference of high-risk professions and hold to their faith for medical philosophy proceeding from the reality of the students; they increase running distance in a scientific manner and succeed through exercising step by step. It indicated that students can achieve teaching goals as long as they consciously practice. Senior teachers Zhou Yafei, Zhou Yinghong from attached middle school of Nanchang Normal University organized three dimensional teaching experiment to support their own belief of sports science, successfully organization module and three dimensional teaching experiment, significantly improve students' endurance quality (the high schools boys entering schools in 2008 up standard in 1000 meters running and that of girls in 800 meters, respectively climbed from by $76.85 \%$ to $94.59 \%$ and $73.55 \%$ to $96.78 \%$ ) (Table 1 )

TABLE I. TARgEt HitTing Statistics OF MALES AND FeMAlES RunNing MOdULE TEACHING (1 CREDIT)

\begin{tabular}{|c|c|c|c|c|c|c|c|c|}
\hline $\begin{array}{l}\text { Target- } \\
\text { hitting } \\
\text { level }\end{array}$ & male & $\begin{array}{l}\text { Student } \\
\text { s below } \\
\text { standard }\end{array}$ & $\begin{array}{l}\text { Students } \\
\text { up } \\
\text { standard }\end{array}$ & $\begin{array}{l}\text { Rate of } \\
\text { reachin }\end{array}$ & female & $\begin{array}{l}\text { Students } \\
\text { below } \\
\text { standard }\end{array}$ & $\begin{array}{l}\text { Students up } \\
\text { standard }\end{array}$ & \multirow{2}{*}{$\begin{array}{c}\text { Rate of } \\
\text { reaching } \\
\text { standard } \\
\text { U/P }\end{array}$} \\
\hline $\begin{array}{l}\text { Teach- } \\
\text { ing } \\
\text { period } \\
\end{array}$ & N & $\begin{array}{c}\geq 5^{\prime} 14^{\prime \prime} \\
(\mathrm{n}) \\
1 \%\end{array}$ & $\begin{array}{l}\geq 5^{\prime} 14^{\prime \prime} \\
-\geq 3^{\prime} 50^{\prime \prime} \\
\text { (n) } / \%\end{array}$ & $\begin{array}{c}\mathrm{g} \\
\text { standar } \\
\mathrm{d} \\
\mathrm{U} / \mathrm{P}\end{array}$ & $\mathrm{N}$ & $\begin{array}{l}\geq 5^{\prime} 11^{\prime \prime} \\
\text { (n) } 1 \%\end{array}$ & $\begin{array}{l}\geq 5^{\prime} 10^{\prime \prime} \\
-\geq 3^{\prime} 50^{\prime \prime} \\
\text { (n) } / \%\end{array}$ & \\
\hline $\begin{array}{l}2008 \\
\text { (begin } \\
\text { ning of } \\
\text { semeste } \\
\text { r) }\end{array}$ & & $\begin{array}{l}(47) / \\
23.15\end{array}$ & $\begin{array}{l}(156) / \\
76.85\end{array}$ & & & $\begin{array}{l}(41) / \\
26.45\end{array}$ & $\begin{array}{l}(114) / \\
73.55\end{array}$ & \\
\hline $\begin{array}{c}2009 \\
\text { (end } \\
\text { of } \\
\text { semeste } \\
\text { r) }\end{array}$ & 203 & $\begin{array}{l}(11) / \\
5.41\end{array}$ & $\begin{array}{l}(192) / \\
94.59\end{array}$ & $\begin{array}{l}5.11 / \\
<0.01\end{array}$ & 155 & $\begin{array}{l}(5) / \\
3.22\end{array}$ & $\begin{array}{l}(150) / \\
96.78\end{array}$ & $\begin{array}{l}5.75 / \\
<0.01\end{array}$ \\
\hline
\end{tabular}


Zhou Fei adhered to the scientific concept of sports and overcame the sudden death in running and a crisis of confidence. Supported by leaders in the school and his peers, he insisted on hard teaching experiment for three semesters and two academic years. He wrote the essay "Guiding PE teaching with concept of scientific development" with great achievements, published as Forth volume phase third on "theoretical research of Fitness Club. And today in order to extensively carry out campus football meeting children' interest, we should implement reform of PE curriculum in primary and secondary schools with confidence and stick to our beliefs. We should mainly focus on developing students' endurance quality, processing materials in three-dimensional way, to carry qualified campus football based on improving the quality of physical education in primary and secondary schools. ${ }^{\text {[31 }}$

\section{B. Campus Football Should Be Carried out Based on Curriculum Reform with High Quality}

PE curriculums are the body-building classes compulsory for all primary and secondary school students. Convenient transportation and electrification replace the heavy manual labor; children have become more and more lazy in affluent life with rare participation in physical exercise, especially the boring and strenuous running exercise, which is the root of decline of adolescent physical strength and cardiopulmonary dysfunction. It's also the important obstacle that affects the stable and high-quality development of campus football. Children' campus football is the main basic training of body and technology, which means that to carry out campus football, must be based on the its characteristics. The primary task is to improve students' physical health in order to reform PE teaching at school and improve the quality of teaching. Can the solid first step of achieving the dream of powerful country with football only through strengthening the scientific management of the campus football.

The physical testing data of national youth in 2010 showed that the boys' 1000 meters endurance running and girl's 800 meters running aged 13-18 in middle school have dropped 9.6 seconds and 12.6 seconds respectively; and this fully reflected that to carry out the campus football must give priority to implement the reform of PE curriculum and put teaching quality and in the first place, which is not only important to improve the physical quality of all the students but also relevant to carry out campus football. "the young are strong, then the China will be strong". Only youth in good health, can they study better, work better and participate in national defense construction. People have become inactive in long time with the life becoming richer. Besides, the establishment of teaching content, teaching plan, selection of teaching methods and scientific management etc are also involved; and the key point lies on strengthening the management of physical education consciousness, which is the management of people. Because the teaching subject are children living in rich life, majority of them have developed inactivity out of parents' indulgence. And the sudden death of individual students happened during endurance running test has adversely effected the implementation of running ; what teacher Zhou impressed most in his successful endurance running experiment was teaching responsibility and scientific teaching attitude. Strengthening the ideological education work to teaching objects and parents and enhancing parents' support to sports to achieve teaching goals under the leadership of leaders in schools.

Endurance running must been taken as the break-through to achieve the basic teaching goal of improving students' physical quality. And it must be put into practice through students' spontaneous participation in exercising. Students living far from school go to school by bike, and those near school run or walk to school instead of by car. Some students choose to walk upstairs rather than take the elevator to increase leg strength training. The health effects enable students to truly realize the "walking and running is the basic human survival activities". Can lung capacity be increased and functions of cardiovascular system be improved only through developing endurance running abilities. To enlarge the functions of students' spontaneous learning can ensure inspiration and motivation to teaching objects be achieved and inspire them to consciously participate in endurance exercise to promote development pf campus football with high quality.

The PE curriculum must be based on the physical and mental situation teaching objects and choose teaching contents for teaching design in a scientific manner and define organization and teaching methods. The primary and secondary schools students are in period nod-developing in the need of walking, running, jumping, throwing and outside activities to fulfill the children' physical basic education with all-round development of children' physical and mental health, Therefore, the teaching design of sports curriculum in primary and secondary schools must be based on "three-dimensional" (physical, psychological and social adaptation ability) health to carry out module teaching design and the teaching process. The track and field teaching materials in the basis of running run through to the jumping, throwing and 3D games and ball games so as to fulfill the implementation of three-dimensional modular teaching (Fig.1. two) .

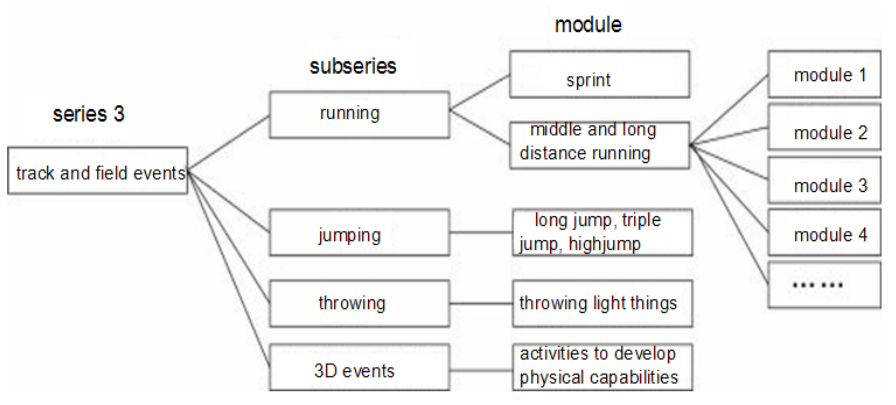

Fig. 1. Modules of Track Events

All sports come with body moving. The development of physical ability starts from walking and moving. To carry out develop campus football, first priority must be given to PE teaching in primary and middle school. First of all, it's 
necessary to have PE classed in primary and middle schools and organize the three-dimensional modular teaching scientifically and meticulously. We should attach most importance to track and field aiming at developing students' physical and mental health and strengthening students' physical strength so as to better improve their basic technique and skills of running and kicking balls. The functions of every small modules can be released and amplify that of the whole modules by various teaching organizations and methods with teaching plans made according to teaching goal. In order to better carry out campus football, we must strengthen the targets management of physical education with scientific organization and implementation of digital teaching management, to output positive energy to the teaching and complete teaching goals successfully. ${ }^{\mathbf{I} \mathbf{I}}$

All schools advocated that the "planning, organizing and control" were managing procedures of achieving the final goal of PE teaching. The target task of any managing system is the start of managing process as well as the end.

In the teaching system of PE in primary and secondary schools, PE class teachers are the teachers, the organizers and the managers in teaching process. According to functions of natural attribute by pressing influence on the body health and social attribute by educating parents and families about physical consciousness, teachers scientifically choose teaching contents and methods based on characteristics of students' age and body and to inspire students to do physical exercises consciously and develop good exercising habits in order to achieve the ultimate goal of developing and enhancing students' physical strength.

There are still difficulties in accomplishing the teaching task of physical education in primary and secondary schools at the present stage, because nowadays majority of children lack of physical exercise. And under the negative influence of students' sudden death during running and endurance running tests a few years ago, schools delisted the endurance running in PE classes. As a result, we have to take scientific attitude towards highlighting endurance running to match with the implementation of campus football and strengthen scientific management of teaching system. Teachers, as managers of teaching system, should be responsible for students' health with a high sense of responsibility. At first, they need to understand and fully grasp the health situation of students before making teaching plans and designing reasonable exercise load. And they need to carefully test students' heart and lung function before endurance running, including their basic heart rate, heart recovery rate after sporting and respiratory frequency.

Design of exercise physiological load in endurance running teaching should be reasonable under the healthy principle of physical exercise. The heart rate should be controlled at about 125-165 (times/m) got from human bodies' nearly limited heart rate 220 (times $/ \mathrm{m}$ ) minus age and multiple by $65-80 \%$. Experienced teachers test load to adjust the amount of exercise with observation and or immediate heart rate and recovery heart rate adjust the amount of exercise. Practices with different natures and levels are required. For example, endurance running has been divided into diverse practices as free jogging, uninterrupted jogging 1000-1500 meters, alternate running and walking and level pace running of 15000-2000 meters. And it can also be combined with playing ball with running in order to improve students' interest, and cultivate outstanding players to the campus football team.

\section{CONCLUSION}

Campus football is now emerging at primary and secondary schools in major cities in our country. As far as the reform of our sports and physical education are concerned, it's like spring breeze waking up every corner of schools and injecting new vitality to the reform. Modern football shares the same demand and direction with the reform of our physical education in primary and secondary schools. It requires playing the ball with running as well as fundamental endurance running capacity; while the track and field running is exactly not favored by students. But they prefer playing football, an activity game which suit in the goal of threedimensional health in physical education. Campus football and the reform of physical education curriculum have the exactly same goal.

Campus football is the first basic step to achieve the dream of powerful country of football and be geared to the international standards. Football should start from the kids. But its teaching objects are tremendous primary and secondary school students. The level of students' physical development and physical quality are the decisive factors of carrying out campus football and improving the technological level of China's football. Therefore, the deepening reform of PE curriculum in primary and secondary school, according to the main feature "running and kicking ball "of football, should be based on the track and field with endurance running at the core to develop teaching plans. Deepening the reform of physical education and improving the quality of teaching, should be included in the positive efficiency of high-level program of sports management system and feedback system

\section{REFERENCES}

[1] Zhang Rui, "Analysis and solutions towards the situation of campus football implementation in primary and secondary schools in Nanchang," (postgraduate and doctoral essay), 2013.

[2] Cui Yongyuan, On the semi-military management close to minute in Hengshui High school, www.cnhuadong.net/syst

[3] Guo Suzhi, "On health education and reform of PE curriculum Journal of Jiangxi Institute of Education, vol. III, 2002, pp. 85-87.

[4] Zhou Fei and Zhou Yinghong, "Guiding PE teaching in high school with scientific development theory---The teaching design and target management of the track and field compulsory module," Fitness Club p59-61 